\title{
ARTIGO
}

do https://doi.org/10.22481/praxisedu.v16i39.6375

\section{QUANTITATIVE AND QUALITATIVE COMPONENTS AND INDICATORS OF PRODUCTIVITY IN EDUCATIONAL CENTERS}

\author{
COMPONENTES CUANTITATIVOS Y CUALITATIVOS E INDICADORES DE \\ PRODUCTIVIDAD EN CENTROS EDUCATIVOS
}

\section{COMPONENTES QUANTITATIVOS E QUALITATIVOS E INDICADORES DE PRODUTIVIDADE EM CENTROS EDUCACIONAIS}

\author{
Amir Hassan Talebian \\ Islamic Azad University - Iran \\ Gholamreza Vaisi \\ Islamic Azad University - Iran \\ Seifollah Fazl Ellahi \\ Islamic Azad University - Iran
}

\begin{abstract}
The role of human resources in promoting productivity of service organizations is important due to the direct production and delivery of human services. Applying manpower motivated, empowered and productive, in addition to providing quality services, can utilize other resources within the organization efficiently and desirably and realize the various aspects of productivity and ultimately benefit the organization. Therefore, the purpose of this article is to quantitative and qualitative components and indicators in educational centers. This research was practical and descriptive. The population of this study included all educational centers in 2018. Sample size was estimated based on Krejcie and Morgan Table (123 people) that selected by stratified random sampling. Data collection tool was a questionnaire consisting of 4 components of educational requirements ( 4 items), quantitative indicators of education (4 items), qualitative indicators of education ( 8 items), external environment specificity (6 items), indoor environmental characteristics ( 7 items), characteristics of psychological environment (11 items) and strategic human resource management (5 items) that based on a five-point Likert scale from strongly disagreed to strongly agreed. The content validity of the questionnaire was confirmed by expert opinion. Cranach's alpha coefficient of the variables was also higher than 0.7 that indicating internal consistency of the items and confirmation of reliability. Partial least squares method was used to test the research model by using PLS software. Based on the results, all identified components were significant in the default conceptual model and only the components of "quality of
\end{abstract}


education" and "characteristics of the psychological environment" did not have a significance in forming the model of educational productivity in the present study.

Keywords: Quantitative and Qualitative Components, Qualitative and Quantitative Indicators, Educational Centers, Productivity.

Resumen: O papel dos recursos humanos na promoção da produtividade das organizações de serviços é importante devido à produção e entrega direta de serviços humanos. A aplicação de mão-de-obra motivada, capacitada e produtiva, além de fornecer serviços de qualidade, pode utilizar outros recursos dentro da organização de maneira eficiente e desejável e realizar os vários aspectos da produtividade e, finalmente, beneficiar a organização. Portanto, o objetivo deste artigo é componentes e indicadores quantitativos e qualitativos em centros educacionais. Esta pesquisa foi prática e descritiva. A população deste estudo incluiu todos os centros educacionais em 2018. O tamanho da amostra foi estimado com base em Krejcie e Morgan Table (123 pessoas) selecionadas por amostragem aleatória estratificada. A ferramenta de coleta de dados foi um questionário composto por 4 componentes de requisitos educacionais (4 itens), indicadores quantitativos de educação (4 itens), indicadores qualitativos de educação (8 itens), especificidade externa do ambiente (6 itens), características ambientais internas ( 7 itens) ), características do ambiente psicológico (11 itens) e gestão estratégica de recursos humanos (5 itens) que, com base em uma escala Likert de cinco pontos, de fortemente discordado a fortemente aceito. A validade do conteúdo do questionário foi confirmada pela opinião de especialistas. $\mathrm{O}$ coeficiente alfa de Cranach das variáveis também foi superior a 0,7 , indicando consistência interna dos itens e confirmação de confiabilidade. O método dos mínimos quadrados parciais foi utilizado para testar o modelo de pesquisa usando o software PLS. Com base nos resultados, todos os componentes identificados foram significativos no modelo conceitual padrão e apenas os componentes "qualidade da educação" e "características do ambiente psicológico" não tiveram importância na formação do modelo de produtividade educacional no presente estudo.

Palavras-chave: Componentes Quantitativos e Qualitativos, Indicadores Qualitativos e Quantitativos, Centros Educacionais, Produtividade.

Resumo: El papel de los recursos humanos en la promoción de la productividad de las organizaciones de servicios es importante debido a la producción y entrega directa de servicios humanos. La aplicación de mano de obra motivada, empoderada y productiva, además de proporcionar servicios de calidad, puede utilizar otros recursos dentro de la organización de manera eficiente y deseable y darse cuenta de los diversos aspectos de la productividad y, en última instancia, beneficiar a la organización. Por lo tanto, el propósito de este artículo es para componentes e indicadores cuantitativos y cualitativos en centros educativos. Esta investigación fue práctica y descriptiva. La población de este estudio incluyó todos los centros educativos en 2018. El tamaño de la muestra se estimó en base a Krejcie y Morgan Table (123 personas) que seleccionaron mediante muestreo aleatorio estratificado. La herramienta de recolección de datos fue un cuestionario que consta de 4 componentes de requisitos educativos (4 ítems), indicadores cuantitativos de educación (4 ítems), indicadores cualitativos de educación (8 ítems), especificidad del ambiente externo (6 ítems), características ambientales interiores ( 7 ítems) ), las características del entorno psicológico (11 ítems) y la gestión estratégica de los recursos humanos (5 ítems) que se basa en una escala Likert de cinco puntos desde muy en desacuerdo hasta muy de acuerdo. La validez de contenido del cuestionario fue confirmada por la opinión de expertos. El 
coeficiente alfa de Cranach de las variables también fue superior a 0.7, lo que indica la consistencia interna de los ítems y la confirmación de confiabilidad. Se usó el método de mínimos cuadrados parciales para probar el modelo de investigación utilizando el software PLS. Con base en los resultados, todos los componentes identificados fueron significativos en el modelo conceptual predeterminado y solo los componentes de "calidad de la educación" y "características del entorno psicológico" no tuvieron un significado en la formación del modelo de productividad educativa en el presente estudio.

Palabras clave: componentes cuantitativos y cualitativos, indicadores cualitativos y cuantitativos, centros educativos, productividad.

\section{Introduction}

Organizations are considered as an essential part of today's societies. The types of services and products needed by the community are provided by various organizations, all of which require organizational effectiveness to be sustained. Educational organizations are one of the most important organizations responsible for the formal education of the community and in this regard, schools as an essential part of the formal education organization are striving to achieve the goals of education (Lee et al. 2017). The most important factor in improving productivity in any organization and in any country is manpower. This factor has become an essential element in explaining the differences in productivity and growth in different countries. Organizations that have had significant successes and those that are among the most developed countries have put this issue at the forefront of their work (Jones, Calmy, \& Kayhan, 2006).

Human resource productivity is one of the essential factors for countries to achieve scientific and industrial progress and ultimately economic development. Since the main basis is human development, improving the quality of human resources in development is essential and any planning for human resource development plays a crucial and decisive role (Gil-Alana \& Modida, 2018).

The comprehensive development of the educational system and its interconnection with all social, economic, political, cultural, and other institutions and organizations, as well as the large number of students and human resources, ie "teachers and staff", and the allocation of enormous financial resources, it has a lot of issues with this system. At the beginning of the third millennium, different countries around the world at different levels of growth and development realized that educational organizations like other organizations need careful and intelligent management. Educated and experienced managers should use the science and art of 
problem management to reduce and direct the educational system to prosperity (Qara'i Moghadam, 1375: 8).

Productivity is the effective and efficient use of resources and institutions such as labor, capital, materials, energy and information. In other words, efficiency is the optimal use of inputs to achieve more outputs. The importance of focusing on productivity in many countries, productivity, proper using, and better from the sum of the factors of production (goods or services) have become a national priority and it has been attempted to institutionalize the slogan that sustaining the life of any society, no matter how difficult. However, planning is necessary to improve productivity at different organizational, regional, national, and even personal levels. But improving productivity in today's competitive world is one of the most important goals and strategies of any organization's success (Brothers \& Valijani, 2015).

Today, increasing productivity in organizations is one of the main concerns of executives and decision-makers in every country, therefore, many countries focusing their productivity growth programs. Over the past 15 years, global productivity gains have increased 45 times. Productivity contributes to improving the standard of living and reducing inflation, on the other hand, resulting in changes in relative prices, an increase in real production, and a more efficient allocation of resources. In general, economic growth in countries depends on their productivity growth (Isaacia, 2015: 5).

Today, all countries are seeking productivity in the world. Improving productivity in organizations enables people to think, innovate, systematic attitude, and the idea of aiming instead for the present and the past, to create and build the future. During the last two decades, the need to create and expand productivity sector and a comprehensive productivity management in organizations has become increasingly important (Rosales, 2015: 47).

Among the factors of production, the human factor unlike other sources has a high level of understanding and influence on the better use of other factors of production. In other words, the most important lever is in increasing and decreasing the productivity of organizations. Therefore, it has a special place in the improvement of productivity and should be given special attention. The role of human resources in promoting the productivity of service organizations due to the direct production and delivery of human services. Applying manpower motivated, empowered and productive, in addition to providing quality services, can utilize other resources within the organization efficiently and desirably and realize the various aspects of productivity and ultimately benefit the organization. So the main question 
of this research is what are the quantitative and qualitative indicators, components and indicators in educational centers?

\section{Evaluation and measurement of quantitative and qualitative components of human resources productivity}

\section{Training and development of the human}

Effective education and training of human resources (as distinct source of knowledgebased organization), is consider as a strategic factor in achieving the productivity and growth and development in the context of a different dynamic. Communities and organizations should educate people more than they care about budgets, costs and industries. After defeating communist ideology, Gorbachev said: "They have to look at the world with a new perspective and see man as the center of everything". To provide the ground for each individual to move towards using their abilities (Anabi, 2017).

\section{Promoting fundamental values like human resources:}

Establishing the right human relationships will lead to a successful organization with efficient human resources. Whenever an organization respects its people and their personality, their talents and abilities will be nurtured because it is only with this manner can conquered the hearts of human (Annabi, 2017).

\section{Humiliation:}

The manager's relationship with the people in the organization should be like the father-child relationship. As family members treat each other emotionally and sincerely, the relationships between individuals and managers should like that in the organization. One of the most important features of Japanese management is paternal interaction with employees like treat and support their children as a father and even solve their family problems (Lee \& Tana, 2019).

\section{Waste reduction:}


One of the ways of increasing the productivity is to reduce waste. Waste and its increasing is one of the mass production phenomena in which industrialized countries including Europeans that they are seeking ways to prevent and stop this process. Waste reduction is one of the basic principles of human social life that has been used for thousands of years without knowing its meaning. The issue of cutting off or reducing waste stream as well as avoiding inevitable waste is particular importance due to the large volume of wasted resources and potential environmental damage. If we accept the principle that we need to have a proper and effective plan for waste reduction, a comprehensive executive plan to coordinate the actions and efforts of all the departments and units of the organization is inevitable. This program guides the organization's efforts to meet waste management needs and tools. Reducing waste reduces stress in the organization and creates an atmosphere of trust and confidence among employees that encourages them to more cooperate (Algecil et al., 2011).

\section{Continued commitment of manpower and its creation:}

Committed manpower is very valuable in any organization. This distinct organizational resource can be effective in enhancing productivity by delivering timely work and a sense of responsibility. So try to train committed employees for the organization. Managers can commit to the organization by meeting the basic needs of their employees, building mutual trust between themselves and them, and creating a culture free of blame. They will never feel fully committed to the organization until the psychological needs of the staff are met. It is not enough just to make employees committed to the organization, but to always keep their commitment to the organization. One of the most effective ways to keep employees engaged and keep them in the organization is to enrich their jobs and increase their motivation (Annabi, 2017). Appreciating individuals for their superior performance is an incentive to maintain employee commitment and job satisfaction. The use of financial incentives such as salary increases, incentive payments, etc. for exceptional and highly productive employee performance is important in maintaining employee commitment. It should be noted that the value and profound impact of using simple terms such as thank you and etc. Don't underestimate the simple things because they create a commitment in the employees and thereby increase their activity and productivity (Barrow et al., 2013).

\section{Paying attention to productive manpower needs}


An organization can be successful by investing effectively in its human resources. Therefore, well thought out organizations always pay special attention to continuous improvement of the quality of their employees and this pattern of behavior in managers of organizations leads to waste reduction and product quality improvement, which ultimately results in increased productivity.

Giving people new or better jobs shows that you respect to their success. This will encourage them to make more success. Paying attention to the human resources as human beings and expressing interest in their welfare, health, desires and aspirations will improve their performance and increase productivity. One of the most productive and satisfying tasks a manager can do, identifying and using individual talents that can be used as a powerful tool to increase productivity. In organizations especially large organizations often individual talents are not fully exploited and sometimes they remain completely unknown. That is, potential talent is not used to increase productivity, which is itself a lost opportunity to increase productivity. Therefore, managers should try to discover abilities that are not fully utilized and find better ways to use them more effectively in order to increase productivity (Lee \& Tana, 2019).

\section{Staff Motivation and Motivation}

Financial resources are not the only component of motivation in an organization's workforce. If people's rights are too low, they lose motivation. As a result, financial rewards remain a strong incentive for them. Therefore, try to use incentive rewards as a way to share employees with the success of the organization and the productivity of it, not as a motivating factor. In other words, employees should understand that they share the benefits of what they do. The biggest motivating factor for individuals is to show them that they are somehow owned by the organization and it is the workers' contribution to the productivity of their work that in turn to increases productivity. On the other hand, the remuneration paid or the workers' contribution to their productivity must be fair, otherwise it may have the opposite effect. In other words, the benefits of productivity must be fairly distributed between management and workers. High productivity is more valuable to people than extra payments, but everyone loves a fair reward. Individuals want the reward they receive to be commensurate with their effort. Therefore, they will be more committed to new ways of working. Otherwise, they will resist unfair payments and your thoughts may be passive and may reduce productivity. If you need 
people but cannot find them, if they do not attend meetings and do not participate in discussions if they are present (Lee \& Tana, 2019).

\section{Literature review}

Maslahi and Salahi Kojour (2016) in an article entitled relationship between managers 'power and time management with human resource productivity concluded that there is a positive and meaningful relationship between managers' power and time management with productivity. Also, between the components of managers' power (reward, law, authority, and expertise, and time management components of targeting, operation planning, delegating authority, communication management, and meeting management) with staffing productivity in sports and staff departments. There is a relationship between the youth of Mazandaran province. But there is no relationship between the components of coercion and the prioritization of goals and activities.

Alipour and Parsania (2015) conducted a study on factors affecting productivity in the organization (Case study: all employees of Ahvaz Islamic Culture and guidance office). The results show that personal characteristics, organizational structure, management style, reward system, physical space, organizational culture are effective on employee productivity.

Brothers and Valijani (2015) conducted a study on the factors affecting the promotion of human resource productivity in the tax administration of Iran (Case study of the General Tax Administration of East Tehran). The results of statistical analysis show that three factors of organizational, personal and environmental characteristics have the most impact on productivity promotion, respectively.

Hosseini Nodehi (2012) conducted a study on strategic human resources factors affecting increasing human resources productivity. The results showed that continuous job training of managers and employees, promotion of motivation among employees for better and more work, creation of suitable areas for initiative and creativity of managers and employees, establish a proper performance-based payment system, establishing a system of punishment, encouragement, and work conscience had an effect on increasing the productivity of the workforce.

Bush and Jackson point to the relationship between leadership quality and school effectiveness. One way to ensure that educational leaders play their role effectively is through professional development and training. 
Paterson et al. (2004) have shown that the concern of managers at higher levels of education systems to ensure the well-being of teachers and teachers in primary and secondary education has led to the satisfaction and thus efficiency of teachers.

Haber (2006) mentioned that school effectiveness studies as claiming that schools' success is largely due to their having worthy, competent, expert, and responsible leadership and their failure often with inadequate leadership is correlated. Today, in the 21 st Century, there is a great deal of support for the perception that management is a specialized profession and hence requires dedicated development and preparation.

Bush believes what that supports the specific preparation of leaders, evidence is that leadership quality plays a vital role in improving schools and students' results and achievements.

Stewart (2015) conducted a study on the relationship between source of power and job enrichment with time management of managers. The results showed that there was a direct and significant relationship between the five sources of power (authority, expertise, coercion, remuneration, and law) with time management, and there was an inverse relationship between managers' power and job enrichment.

\section{Research Methodology}

The method of this research is combinatorial type including of qualitative and quantitative. In the first part, which is based on qualitative research method, by studying the research and scientific documents of libraries as well as through semi-structured interviews with academic elites and experts, effective indicators and components of interest model formulation performance of elementary school principals and teachers will be identified in Kashan. Then, in the framework of the quantitative research method, the proposed model based on the qualitative analyzes of the previous section has to be approved and proved at a certain level of confidence.

\section{Research population}

The research population of this research includes all primary schools in Kashan in 1397. In the qualitative sector, there were 12 experts in the field of educational management and academic experts. Experts participating in Delphi have one or more of the following 
attributes: a faculty member specializing in educational management and human resource productivity; principals, deputies and educational experts and teachers with at least 5 years' experience or experience in Educational Management Area.

\section{Sample size}

Because of the size of most research communities is large, it is not possible to measure the specificity of the study for each individual or community. Therefore, samples are used to represent the community in question. The Krejcie and Morgan sample size estimation table was used to determine the sample size, which is 123 persons based on this table. In the qualitative sector, there were 12 experts in the field of educational management and academic experts in educational management and science.

\section{Sampling method}

Sampling is a step in the interconnected stages of scientific research and one of the essential elements of the methodology of new science. The purpose of sampling as a research tool is to facilitate research work. Sampling allows the researcher to achieve the desired results by spending less. Stratified random sampling method was used in this study. In this way, from February to March, based on the statistics of primary schools in the city of Kashan were selected and the necessary information was obtained. In the qualitative part, the components and factors are identified using the Delphi method when research is about specific groups that are not easily identifiable. This method helps to reach other members of the group by finding one or more of the research team by getting the available members.

\section{Data collection}

There are several methods for collecting information and several research methods may be used in one study. The information collected in each research should be selected according to the research objectives, research method and sample characteristics. Therefore, according to the nature of the research, the process of data collection was three stages: first step: to complete the theoretical foundations, the library method (reading books, articles, and 
research) was used; second stage: the field method was used to collect the required data using a questionnaire from educational experts and managers.

The most important research tools are library studies, interviewing experts and questionnaires. The Delphi technique has been used as the most important method for verifying the extracted components in this research. Then, using structural equation modeling, model fitting was performed. Two methods of extensive library study and expert interviews were used to extract the primary components.

The primary tool for collecting data in this study is a questionnaire based on a review of theoretical literature. The first part of the questionnaire is about the general and demographic questions of the respondents and the second part consists of specialized questions, some of which are related to educational management variables. The questionnaire included 4 components of educational requirements (4 items), quantitative indicators of education (4 items), qualitative indicators of education ( 8 items), external environment specificity (6 items), indoor environment specificity ( 7 items), psychological environment characteristics (11 items), and strategic human resource management (5 items). The questions are designed on a five-point Likert scale (from 1 in complete disagreement to 5 in complete agreement). The face and content validity of the questionnaire was confirmed by expert opinion.

\section{Reliability or validity}

Validity means that the scale and content of the tool or questions contained in the tool accurately measure the variables and subject under study. To assess the validity of the questionnaires, the questionnaire was administered to the supervisor and specialist professors in the field of organizational management and resources and after making their comment, the necessary corrections were made, so content validation was used to measure the validity.

The purpose of the reliability of a measurement tool is to measure how similar, accurate and reliable the results obtained when we re-measure the attribute with the same instrument under similar conditions. The most commonly used method of reliability testing is the so-called Cronbach's alpha. In this research, Cronbach's alpha test was used to measure the reliability of research scales. To assess the reliability of the sample, one-tenth of the sample size was completed among the members of the statistical population and after the Cronbach's alpha was calculated, the alpha obtained in this study should be greater than 0.7 . 


\section{Data analysis}

Partial least squares method with PLS software was used to test the research model. The analytical method of smart PLS or at least partial squares is a relatively new way of constructing regression equations. This method is used for univariate and multivariate regression. So it may have several dependent variables. To associate between dependent variables and independent variables Smart PLS Explanatory variables (independent) creates a new move.

\section{Result}

Data analysis is very important for verification of the assumptions for each type of research. In order to analyze the data collected, descriptive statistics that examine the demographic variables of the research including gender, educational level, field of study, etc (Table 1).

Table 1. The qualitative status of this study

\begin{tabular}{|l|l|l|l|l|l|l|}
\hline \multirow{2}{*}{ Variable } & \multicolumn{3}{l|}{ Frequency } & \multicolumn{2}{l|}{ Frequency percent } \\
\cline { 2 - 8 } & Female & Male & Total & Female & Male & Total \\
\hline University professor & 1 & 2 & 3 & $33 \%$ & $66 \%$ & $25 \%$ \\
\hline $\begin{array}{l}\text { Educational } \\
\text { Management Specialists }\end{array}$ & 2 & 0 & 2 & $100 \%$ & 0 & $16.6 \%$ \\
\hline $\begin{array}{l}\text { Human Resource } \\
\text { Productivity Specialists }\end{array}$ & 0 & 1 & 1 & 0 & $100 \%$ & $8.3 \%$ \\
\hline $\begin{array}{l}\text { Managers, deputies and } \\
\text { educational experts }\end{array}$ & 0 & 2 & 2 & 0 & $100 \%$ & $16.6 \%$ \\
\hline Teachers & 1 & 3 & 4 & $25 \%$ & $75 \%$ & $33.3 \%$ \\
\hline
\end{tabular}

\section{Measurement model in the size of the methods}




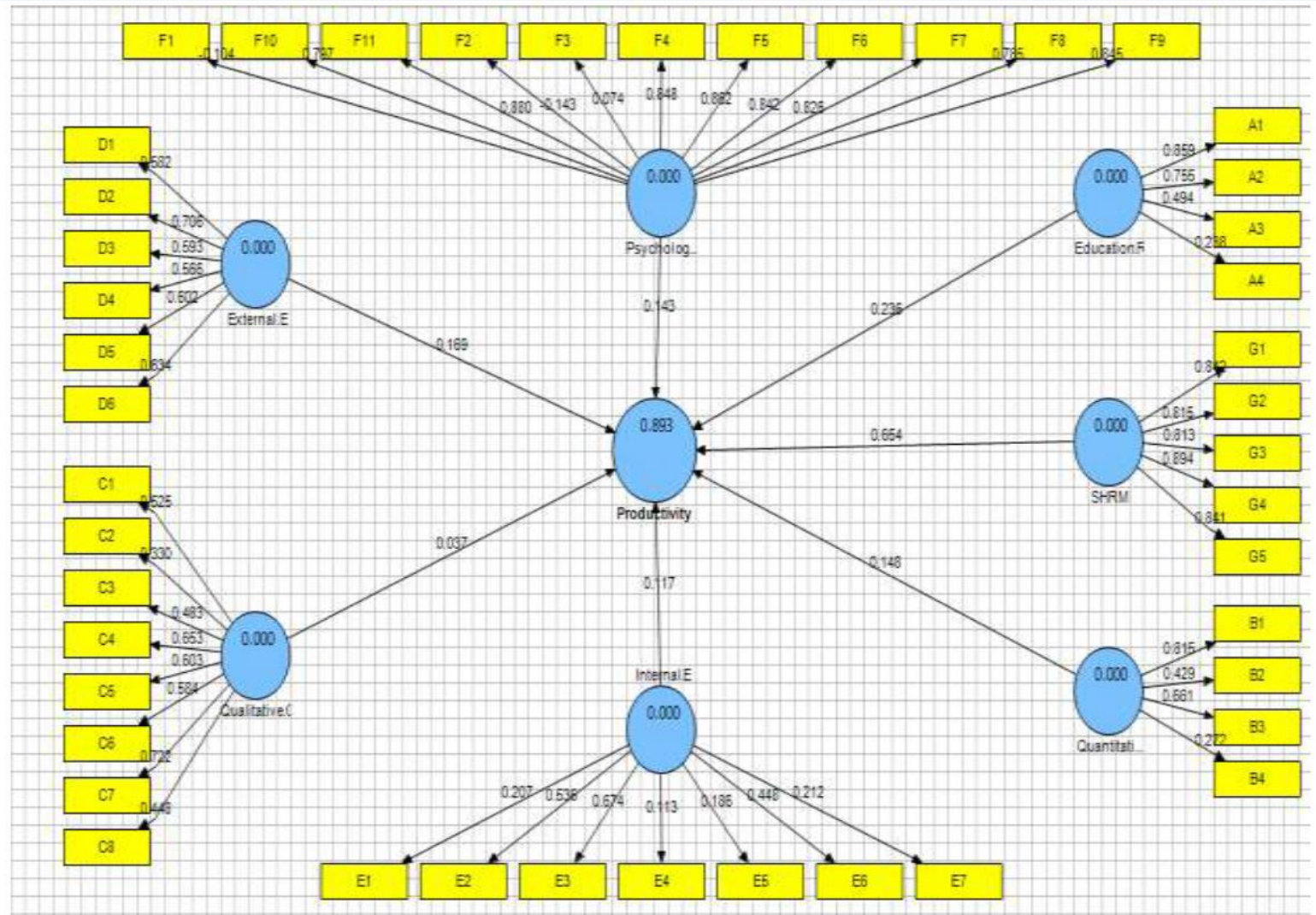

Diagram1. Output methods' the size model making

Table 2. Indicators of the quality of the conceptual model in the size of

\begin{tabular}{|c|c|c|c|c|c|}
\hline $\begin{array}{c}\text { Shared values } \\
\text { (Communality) }\end{array}$ & $\begin{array}{c}\text { Cranach's } \\
\text { alpha }\end{array}$ & $\begin{array}{c}\text { Square } \\
\mathbf{R}\end{array}$ & $\begin{array}{c}\text { Combined } \\
\text { reliability }\end{array}$ & $\begin{array}{c}\text { Average } \\
\text { variance } \\
\text { (AVE) }\end{array}$ & \\
\hline 0.402258 & 0.604571 & & 0.697200 & 0.402258 & Educational Requirements \\
\hline 0.378972 & 0.680622 & & 0.784527 & 0.378972 & $\begin{array}{c}\text { Characteristics of the external } \\
\text { environment }\end{array}$ \\
\hline 0.153999 & 0.260397 & & 0.488171 & 0.153999 & Indoor feature \\
\hline 1.000000 & 1.000000 & 0.892607 & 1.000000 & 1.000000 & $\begin{array}{c}\text { The productivity of teachers } \\
\text { and educational managers }\end{array}$ \\
\hline 0.511594 & 0.840386 & & 0.887486 & 0.511594 & $\begin{array}{c}\text { Features psychosocial } \\
\text { environment knowledge }\end{array}$ \\
\hline 0.309111 & 0.680877 & & 0.773942 & 0.309111 & $\begin{array}{c}\text { Indicators of quality education } \\
\text { Stock quantitative training }\end{array}$ \\
\hline 0.339985 & 0.420715 & & 0.642409 & 0.339985 & Strategic Management of \\
\hline 0.708323 & 0.897046 & & 0.923826 & 0.708323 & Human Resources \\
\hline
\end{tabular}

Based on Table 2, with respect to the values obtained for the AVE criterion, it is known that the highest mean variance shared between the Strategic Human Resource Management $(\mathrm{SHRM})$ variable and its questions (equals the value $=0.7083)$. Therefore, it can be claimed that the most correlations between the questions studied and their variables relate to the Strategic Human Resource Management (SHRM) variable. According to the results, it is clear that the 
values obtained in Cronbach's alpha for all independent and dependent variables studied were at acceptable levels (greater than 0.6). Only Cronbach's alpha values for education and indoor characteristics were lower than 0.6 ( 0.420 and 0.260 , respectively).

Combined reliability index measurement will also study the reliability of each variable in the conceptual model as opposed to the correlation between each variable. According to the results obtained in the qualitative table of the indices in the measurement model, it is clear that with the exception of indoor specificity index (composite reliability equal to 0.4881 ), all indices had composite reliability greater than 0.6 . Therefore, by comparing the results of the Cronbach's alpha indices as well as the composite reliability index, reliability, or in other words, the power of the model designed to accurately measure the target indices can be it was desirable.

\section{Model fitting test (GOF)}

The GOF criterion is related to the comprehensive section of structural equation models that the researcher can then check on the fit of the measurement section and the structural section of the overall research model based on the results of its calculations. The GOF criterion can be calculated using the following equation:

$$
\mathrm{GOF}=\sqrt{\overline{\mathrm{R}^{\uparrow}} * \overline{\text { Communality }}}
$$

Communality (Value share $=$ ) the value of the mean squared factor loadings of each parameter is.

$\overline{\text { Communalit } y}=$ The average value of share any endogenous variables of the model are obtained.

$\overline{\mathrm{R}^{2}}=$ Mean values R Square Variables within the existing model.

In order to calculate the fitting index as it can be seen in the above formula, the measurement of two indexes of common values [8] and the squared coefficient of variation is necessary [9]. According to the results of the above table, it is possible to calculate the fitting index as follows:

$$
\begin{aligned}
& \text { GOF }=\sqrt{(0.892607)^{2} * 0.47553}=\sqrt{0.796747 * 0.47553}=\sqrt{0.37887} \\
& \mathrm{GOF}=0.61553
\end{aligned}
$$

Given the amount of value obtained for the index GOF, will be evaluated overall fit of the model in a satisfactory condition. 
Assess the strength of the expected questions ( $Q^{2}$ (Stone- Geisser Criterion):

Table 3: Measuring the Predictive Power Index of Questions

\begin{tabular}{|c|c|}
\hline 1 -SSE / SSO & Educational Requirements \\
\hline 0.065925 & Characteristics of the external environment \\
\hline 0.136322 & Indoor feature \\
\hline 0.120485 & The productivity of teachers and educational managers \\
\hline 0.813120 & Features psychosocial environment knowledge \\
\hline 0.108234 & Indicators of quality education \\
\hline 0.044882 & Stock quantitative training \\
\hline 0.555434 & Strategic Management of Human Resources \\
\hline
\end{tabular}

According to the results of Table 3, it is clear that the predictive power of the dependent variable "teacher and educational productivity" is 0.813 and given that this value is above the 0.32 threshold, the predictive power of the model under study is highly predictive of the dependent variables of "teacher and educational productivity". The result confirms the predictive power of questions related to the endogenous variable of productivity of teachers and managers, as well as confirmation of model fit results in the structural sector as well as measurement.

\section{Path significant variables to measure influence in AH Elbe conceptual model}




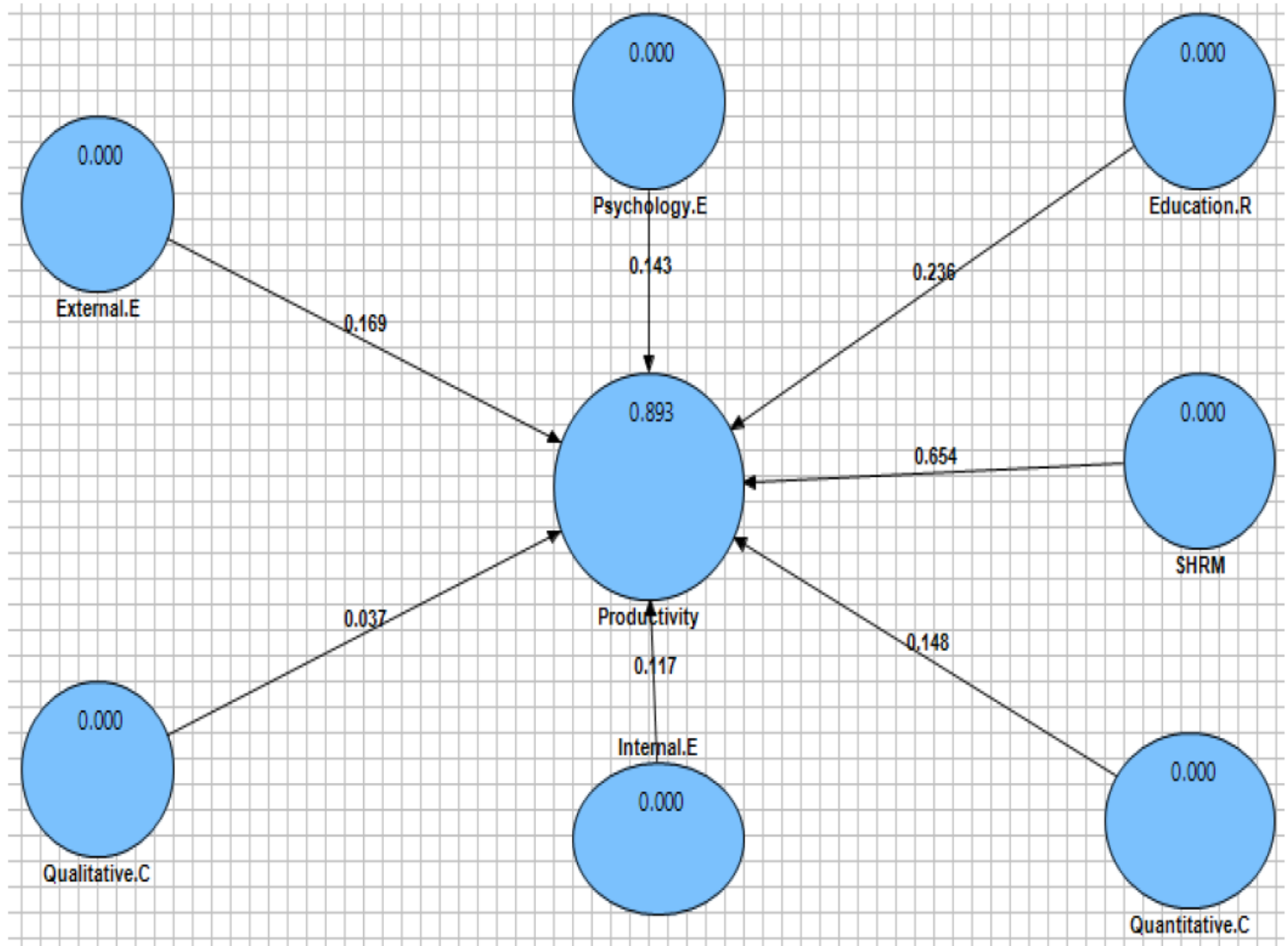

Figure2. The assessment of conceptual model in the model size, measuring,

Table 4. Assess the significance of relationships among latent variables in the model, the size of

\begin{tabular}{|c|c|}
\hline $\begin{array}{c}\text { The productivity of teachers and educational } \\
\text { managers }\end{array}$ & \\
\hline 0.235759 & Educational Requirements \\
\hline 0.168507 & Indoor feature \\
\hline 0.117125 & Features psychosocial environment knowledge \\
\hline 0.143339 & Indicators of quality education \\
\hline 0.037091 & Stock quantitative training \\
\hline 0.147522 & Strategic Management of Human Resources \\
\hline 0.653580 & \\
\hline
\end{tabular}




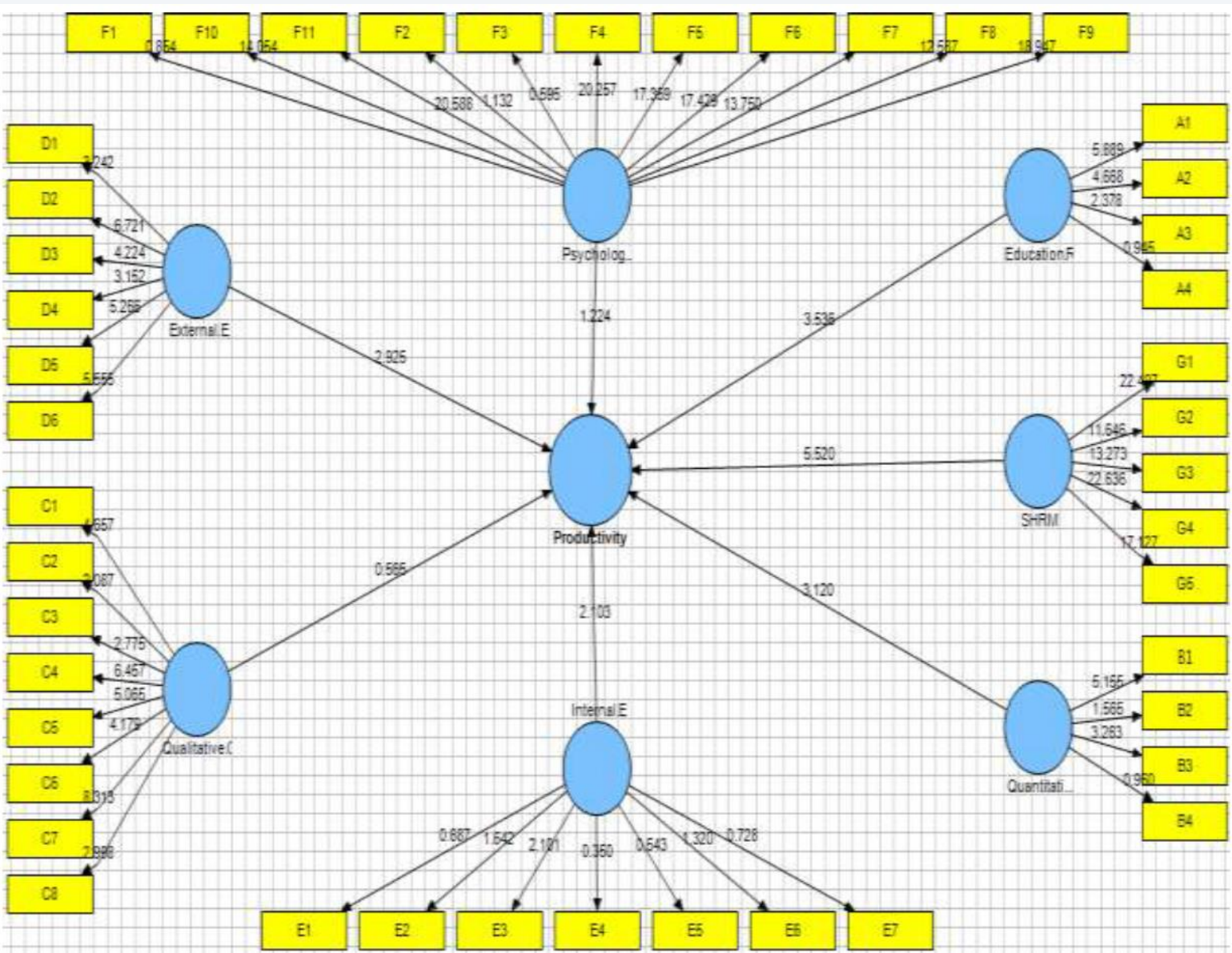

Figure 3. Assessment of the conceptual model and the structural model and significantly influence the severity of the hidden variables causing the output potential

Table 5. Measuring the intensity of the relationships among the hidden variables in the structural part model

\begin{tabular}{|c|c|}
\hline $\begin{array}{c}\text { The productivity of teachers and } \\
\text { educational managers }\end{array}$ & \\
\hline 3.535917 & Educational Requirements \\
\hline 2.924616 & Characteristics of the external environment \\
\hline 2.102521 & Indoor feature \\
\hline 1.223552 & Features psychosocial environment knowledge \\
\hline 0.565346 & Indicators of quality education \\
\hline 3.119965 & Stock quantitative training \\
\hline 5.519576 & Strategic Management of Human Resources \\
\hline
\end{tabular}

After analyzing the results of the T-tests and analyzing the path coefficients in relation to the dependent and sensible variables, it can be concluded that extrinsic variables having a Tvalue greater than 1.96 (at 95\% confidence level) have a significant effect on the exogenous (dependent) variables studied in the context of structural conceptual model and overall structural equation model. Also, T-Value values greater than 2.53 indicate a significant 
relationship between the independent variable and the dependent variable at the $95 \%$ confidence level. T-Value values below 1.96 are also based on the lack of significant effect of the variables studied in the form of regression tests. Based on the analysis, it was found that all the identified components are meaningful in the default conceptual model and only the components of "quality of education" and "characteristics of the psychological environment" have not had a meaningful role in shaping the educational productivity model in the present study.

\section{Conclusion}

According to the results of partial least squares regression test and numerical evaluation of T-test index, it was determined this index is 3.535917 (T-Value $=3.5359$ ) to measure the impact of the main component of "educational requirements" on the productivity of managers and teachers of educational centers in Kashan. Therefore, given that this value is higher than the standard level of 2.53 , it can be claimed at the $99 \%$ confidence level that educational requirements have a significant impact on the productivity of managers and teachers of educational centers in Kashan. Thus, at this level of certainty, the significant claim of accepting the component of "educational necessities" was confirmed as one of the key components in designing the optimal model of productivity of principals and teachers of educational centers in Kashan.

According to the results of partial least squares regression test and numerical evaluation of T-test index, it was determined this index is $2.924(\mathrm{~T}-$ Value $=2.924)$ in assessing the impact of the main component of "external environment attribute" on the productivity of managers and teachers of educational centers in Kashan. Therefore, given that this value is higher than the standard level of 2.53 , it can be claimed at $99 \%$ confidence level that the characteristics of the external environment have a significant impact on the productivity of principals and teachers of primary schools in Kashan. Thus, at this level of certainty, the significant claim of acceptance of the "external environment attribute" component was confirmed as one of the main components in designing the optimal model of productivity of managers and teachers of educational centers in Kashan.

According to the results of partial least squares regression test and numerical evaluation of T-test index, it was determined that this index is $2.102(\mathrm{~T}-\mathrm{Value}=2.102)$ in assessing the impact of the main component of "indoor environment" on the productivity of managers and teachers of educational centers in Kashan. Therefore, given that this value is 
higher than the standard level of 1.96 , it can be claimed at $95 \%$ confidence that indoor environment has a significant effect on the productivity of principals and teachers of educational centers in Kashan. Thus, at this level of certainty, the significant claim of acceptance of the "indoor attribute" component was confirmed as one of the key components in designing the optimal model of productivity of principals and teachers of educational centers in Kashan.

According to the results of partial least squares regression test and numerical evaluation of T-Value index, it was determined that the index is $1.223(\mathrm{~T}-$ Value $=1.223)$ in assessing the impact of the main component of "psychological environment attribute" on the productivity of managers and teachers of educational centers in Kashan. Therefore, considering that this value is lower than the standard level of 1.96, it can be claimed at $95 \%$ confidence level that psychological environment characteristics did not have a significant effect on the productivity of managers and teachers of educational centers in Kashan. Thus, at this level of assurance, the significant claim of acceptance of the "psychological environment attribute" component is not evaluated as influential in designing the optimal model of productivity of principals and teachers of educational centers in Kashan.

According to the results of partial least squares regression test and numerical evaluation of T-Value index, it was determined that this index is $0.5653(\mathrm{~T}-$ Value $=0.5653)$ in assessing the impact of the main component of "Education Quality Index" on the productivity of principals and teachers of educational centers in Kashan. Therefore, considering that this value is lower than the standard level of 1.96 , it can be asserted at $95 \%$ confidence level that the quality-of-education index did not have a significant effect on the productivity of principals and teachers of training centers in Kashan. Thus, at this level of assurance, the significant claim of the component of "quality of education index" is not evaluated as an effective component in designing the optimal model of productivity of managers and teachers of educational centers in Kashan.

According to the results of partial least squares regression test and numerical evaluation of T-Value index, it was determined that this index is equal to $3.1199(\mathrm{~T}-$ Value $=$ 3.1199) in assessing the impact of the principal component of the "quantitative education index" on the productivity of principals and teachers of educational centers in Kashan. Therefore, given that this value is higher than the standard level of 2.53 , it can be claimed at the $99 \%$ confidence level that the "quantitative education index" had a significant effect on the productivity of managers and teachers of educational centers in Kashan. Thus, at this level of assurance, the 
significant claim of the "quantitative education index" component is confirmed as one of the key components in designing the optimal model of productivity of principals and teachers of educational centers in Kashan.

According to the results of partial least squares regression test and numerical evaluation of T-Value index, it was determined that this indicator is $5.519(5.519 \mathrm{~T}$-Value $=$ 5.519 (5.519 T-Value)) in assessing the impact of the main component of "Strategic Human Resource Management (SHRM)" on the productivity of managers and teachers of educational centers in Kashan. Therefore, given that this value is higher than the standard level of 2.53, it can be claimed at the $99 \%$ confidence level that "Strategic Human Resource Management (SHRM)" has a significant impact on the productivity of managers and teachers of educational centers in the Kashan city. Thus, at this level of assurance, the significant claim of acceptance of the component of "Strategic Human Resource Management (SHRM)" is confirmed as one of the main components in designing the optimal model of productivity of managers and teachers of training centers in Kashan.

\section{REFERENCES}

1. Alguacil, M Cuadros, A and Orts, V. (2011) 'Inward FDI and Growth:The Role of Macroeconomic and Institutional Environment '. Journal of Policy Modeling 99 (9), 481-496.

2. Ali Pour, Hadith, Persia, Glory (2015), agents Effective On the productivity At Organization (Study Case: Kidney Employees office Culture And Guidance Islamic Ahvaz), Conference The International Management, Economy And industrial engineering, Tehran: Institute Managers Ideas Processor Capital Vira.

3. and Factors behind Slow Growth, International Journal of Finance and Economics, 23, 111121.

4. Barro, RJ and Lee, JW (2013) 'A New Data Set of Educational Attainment in the World, 19502010'. Journal of Development Economics 104, 184-198.

5. Brothers, Vahid, Valliant, Maryam (2015), A Review Agents Effective On Upgrade However, the productivity the force human in organization Affairs Tax Country (Study Case office Total Affairs Tax East Tehran), Research a Tax, no twenty And Ninth ( machine gun77).

6. Gil-Alana, LA, and Mudida, R (2018), The Growth Rate Series in Kenya: Evidence of Nonlinearities

7. Hosseini Noddy, Seyedeh Maryam (1391), Relation Program planning Strategic Sources human With Productivity Office staff Central Bank Housing, End Letter Masters Senior, College Management, University Free Islamic Tehran Branch Central.

8. Isaac, Amir Hassan, (2015) Review Relation I among Management Criteria Time and Productivity the force human Item Study : Organization Social Security City Yazd, the first Conference National Science Management novel and planning Cultural social Iran, Qom :Center Studies and Islamic Research Soroush Wisdom Mortazavi. 
9. Jones DC, Kalmi P, Kauhanen A (2006). Human resource management policies and productivity:new evidence from an econometric case study. Oxford Review of Economic Policy; 22 (4):526-38.

10. Leta J, Lannes D, De Meis L (2010). Human resources and scientific productivity in Brazil.

11. Li, C Murshed, M and Tanna, S. (2017). 'The impact of the Civil War on Foreign Direct Investment Flows to Developing Countries', Journal of International Trade and Economic Development, 26 (4), 488-507.

12. Li, C Tanna, S The impact of foreign direct investment on productivity: New evidence for developing countries, Economic Modeling (2019), doi:https://doi.org/10.1016/ j.econmod. 2018.11.028.

13. Moslehi, Abdollah, Salahi Kojour, Azim (1395), communication the power Managers And Management Time With Interest Sideways the force Human (at offices Sport And Youth State Mazandaran), National Research Monthly, Vol First, No. 11.

14. Nabil Annabi (2017), "Investments in education: What are productivity gains?", Received 28 November 2016; received in revised form 14 February 2017; accepted 10 March 2017 Available online 9 April 2017, Journal of Policy Modeling 39 (2017) 499-518.

15. Readings First, man A, 7336, Educational Management, Tehran, Publishers Abjad, p.8.

16. Rosales, P. (2015), The relationship between power and effectiveness of nurse managers, Social Science Information, 44 (1):41-63.

17. Scientometrics; 41 (3): 313-24.

18. Stowart, A (2015). The relationship between power supply and job enrichment managing director, European Journal of Scientific Research, ISSN 1450-216X Vol.25 No.2 .PP:143-154.

\section{SOBRE OS AUTORES:}

\section{Amir Hassan Talebian}

PhD student in Educational Management, Qom Branch, Islamic Azad University, Qom, Iran Email: amir_myblog@yahoo.com

(iD http://orcid.org/0000-0002-7044-290X

\section{Gholamreza Vaisi}

Assistant Professor, Qom Branch, Islamic Azad University, Qom, Iran. Email: rezavaisi@gmail.com

(iD) http://orcid.org/0000-0002-6592-6766

\section{Seifollah Fazl Ellahi}

Assistant Professor, Qom Branch, Islamic Azad University, Qom, Iran. Email: fazlollahigh@yahoo.com

(iD) http://orcid.org/0000-0002-5362-3530

Recebido em: 12 de novembro de 2019

Aprovado em: 15 de dezembro de 2019

Publicado em: 01 de abril de 2020 